\title{
単球，血管内皮細胞の活性化とネオプテリン
}

第 1 報 健常小児と炎症性疾患に扔ける血清ネオプテリンの測定と意義

関

$$
\text { 孝*,**・城宏 輔*,**・久保政勝* }
$$

Jpn. J. Clin. Immun., 14 (6) : 593 602, 1991.

\section{Serum neopterin level in normal controls and children with inflammatory diseases}

\author{
Takashi Seki ${ }^{* * * *}$, Kosuke Joh ${ }^{*, * *}$ and Masakatsu Kubo* \\ *Department of Pediatrics, Jikei University School of Medicine \\ **Division of Infectious Diseases, Immunology and Allergy, Saitama \\ Children's Medical Center
}

\begin{abstract}
【Summary】
Neopterin has been recently known as one of the new makers for activated cell-mediated immunity. We studied serum neopterin levels in 114 controls and 83 patients in childfood. Neopterin levels of serum were measured with radioimmunoassay. The group under one year age showed significantly higher serum neopterin levels than the group from the elder. Significantly higher serum neopterin levels were detected in sera of patients with acute bacterial infection, acute viral infection, subacute necrotizing lymphadenitis and active SLE. Particularly in subacute necrotizing lymphadenitis cases and SLE cases, neopterin represented a sensitive marker for the active stage. It seemed that measurement of serum neopterin levels are useful as indicators of these disease states.
\end{abstract}

Key words : neopterin,

SLE,

subacute necrotizing lymphadenitis

\section{【概 要】}

ネオプテリンは in vitroににおいて単球/マクロファージおよび血管内皮細胞が interferon- $\gamma$ (IFN- $\gamma$ ) で刺激 されたときに分泌される低分子物質であり，単球系細胞の活性化の指標として知られている，われわれは血清ネ

*東京慈恵会医科大学小児科

**埼玉県立小児医療センター感染免疫アレルギー科 $(1991 \cdot 7 \cdot 23$ 受付 $)$ 
オプテリンを測定することにより，小児期の各炎症性疾患における単球の活性化を評価することをこの実験の目 的とした．血清ネオプテリンは radioimmunoassayにより測定した，健常小児では 1 歳以下のグループで 1 歳 以上の各年秢別のグループに比べ有意に血清ネオプテリンが上昇した．急性細菌性疾患，ウイルス性疾患， SLE，覀急性壊死性リンパ節炎などの疾患では，コントロールに比べ有意に血清ネオプテリンの上昇がみられ た，亜急性壊死性リンパ節炎およびCNS ループスで血清ネオプテリン值は赤沈値や CRPよりもよく疾患活動 性と平行しており，血管炎ならびに単球系細胞の活性の指標となると考えられた。

\section{I . 緒言}

ネオプテリン, D-erythro-Neopterin はピラジ ノーピラジミン複合体で, guanosine triphosphate (GTP) から産生される低分子物質である ${ }^{1)}$.この物 質の前駆体は D-7，8, dihydroneopterin triphosphateで，単球は他の細胞と異なり， dihydroneopterin triphosphate converting enzyme をもたないた め, L-5, 6, 7, 8, tetrahypobiopterin へ誘導され ず，ネオプテリンを産生するといわれている2．また interferon- $\gamma$ (IFN- $\gamma$ ) で活性化された単球は，ネ才 プテリンの産生量が增加するといわれている3). その ため, T細胞が活性化し, IFN- $\gamma$ の産生が活発にな るような状態では，血清および尿中へのネオプテリン 分泌がえ進し, 活性化T細胞および単球の活性化の指 標になると考えられている4!

In vivoに扔いて，缄器移植の拒絶反応時 ${ }^{5 \sim 8)}, \mathrm{EB}$, サイトメガロ, 単純へルペス等のウイルス感染 時 ${ }^{921}$, live vaccine (麻疹) の接種時 ${ }^{91}$, 敗血症 ${ }^{13)}$, 川1崎病 ${ }^{14}$, 自己免疫疾患 ${ }^{15}$, 覀性疾患 ${ }^{16.17}$ 扝よび AIDS $^{18-20)}$ などで血清および尿中でネオプテリンが 上昇すると報告されている。

これらの報告の多くは HPLC 法によりネオプテリ ンが測定されている。われわれ结必要検体量が少量 でより簡便な方法である RIA 法により小児におけ る各年齢別の血清ネオプテリン值の正常値と各炎症性 疾患における血清ネオプテリン值を検討した．さらに 血清ネオプテリン值と CRP, 赤沈值などとの相関, 臨床経過との関連など血清ネオプテリン值の臨床的意 義について検討した。

\section{II. 対象および方法}

対象は, 健常小児については, 0 歳から 15 歳まで 72 名で, 0〜1歳 22 名, 1〜5 歳 19 名, 6〜10 歳 18 名, $11 \sim 15$ 歳 13 名で, さらに 16〜20 歳 11 名, 21 歳 以上 31 名の健常成人についても検討した.

各疾患別の分類では, ウイルス感染症としたもの
は, ムンプス髄膜炎 $(n=3)$, 水痘 $(n=3)$, 麻疮 $(n=1)$, 単純へルペスウイルス感染症 $(n=3), E B$ ウイルス感染症 $(n=3), B$ 型肝炎 $(n=1), A$ 型肝 炎 $(n=3)$ である. 全例, ウイルス分離あるいは有 意な血清抗体価の上昇により診断した，細菌感染症と しては化膿性髄膜炎 9 名 (Streptococcus agalactie $\mathrm{n}=3$, Streptococcus viridans $\mathrm{n}=1$, Listeria monocytogenes $n=2$, Haemophilus influenzae $n=$ 2, Corynebacterium spp. $n=1$ ) と敗血症 1 名 (Neisseria meningitidis $\mathrm{n}=1$ ) を対象とした. マイ コプラズマ感染症は 9 名で，マイコプラズマ肺炎にて 当科に入院し，有意の血清抗体価の上昇を認めたもの である．亚急性壊死性リンパ節炎は 7 名で，臨床症 状, 白血球数減少, 血小板数減少, 赤沈值の亢進, 特 徵的な免疫学的異常, リンパ節生検所見等から診断し た. SLEは 11 名で，1982 年のアメリカリウマチ協会 の診断基準を満たすものとした. SLEの active stage とは, 臨床症状として, 発熱, 痙攣, 意識障害, 持続 する関節痛, 急性腹症などの症状, 検查所見では抗 dsDNA 抗体の高值, 低補体血症などを認めたときと した. inactive stage とは, active stage 以外のもの とした. JRA は計 19 名で, 診断は厚生省 JRA 研究 班で検討された診断のてびきに従った.JRAの active stage とは, 関節痛の持続, 関節炎の所見, 赤 沈值の高值, CRP の強陽性などの所見が認められた ものとした. inactive stage とは active stage 以外の ものとした.

ネオプテリンの測定は，抗ネオプテリン抗体を使用 した radioimmunoassay（RIA）法によっだ)（へキ スト社).すなわちサンプルに ${ }^{125}$ Iでラベルしたネオ プテリンを入れ，さらに sheep anti-neopterin antiserum, donkey anti-sheep IgG antiserum を加え（二抗 体法), 室温 1 時間 incubate した。その後, polyethylene glycol solution を加え, $2,000 \times \mathrm{g} て 10$ 分間遠 心し，沈査の radioimmunoactivity を測定した。

なお統計学的処理は，すべて student 両側 $\mathrm{t}$ 検定を 使用した。 


\section{III. 結 果}

\section{1. 年齢別血清ネオプテリンの正常值（図 1)}

小児期を 0 1 歳未満, $1 \sim 5$ 歳, 6〜10 歳, 11〜20

歳, 20 歳以上の各年齢における血清ネオプテリンの 正常值を検討した.

$0 \sim 1$ 歳末満のグループは $2.19 \pm 0.96 \mathrm{ng} / \mathrm{m} l て ゙$, 1 5 歳, 6 10 歳, $11 \sim 15$ 歳, $16 \sim 20$ 歳, 21 歳以上 のグループの $1.69 \pm 0.62 \mathrm{ng} / \mathrm{m} l, 1.05 \pm 0.29 \mathrm{ng} /$ $\mathrm{m} l, 1.12 \pm 0.37 \mathrm{ng} / \mathrm{m} l, 1.41 \pm 0.52 \mathrm{ng} / \mathrm{m} l, 1.24 \pm$ $0.34 \mathrm{ng} / \mathrm{m} l$ と比べ, 有意に血清ネオプテリンが上昇
していた（0１歳と 1〜5歳のグループでは $\mathrm{p}<$ 0.05 ，それ以外は $\mathrm{p}<0.01)$.

2. 小児期における各炎症性疾患の血清ネオプテリ ン (図 2)

正常值は, 15 歳以下の健常者の mean \pm 2 SD $(1.55 \pm 1.35 \mathrm{ng} / \mathrm{m} l)$ を正常值として求めた. 麻疹, 水痘, ムンプス䯣膜炎, EBウイルスなどを含めたウ イルス性の疾患では急性期（入院時）において $6.04 \pm 4.16 \mathrm{ng} / \mathrm{m} l$ で正常値と比べ, 有意に高い傾向 を認めた $(p<0.01)$. 化膿性髄膜炎, 敗血症などの

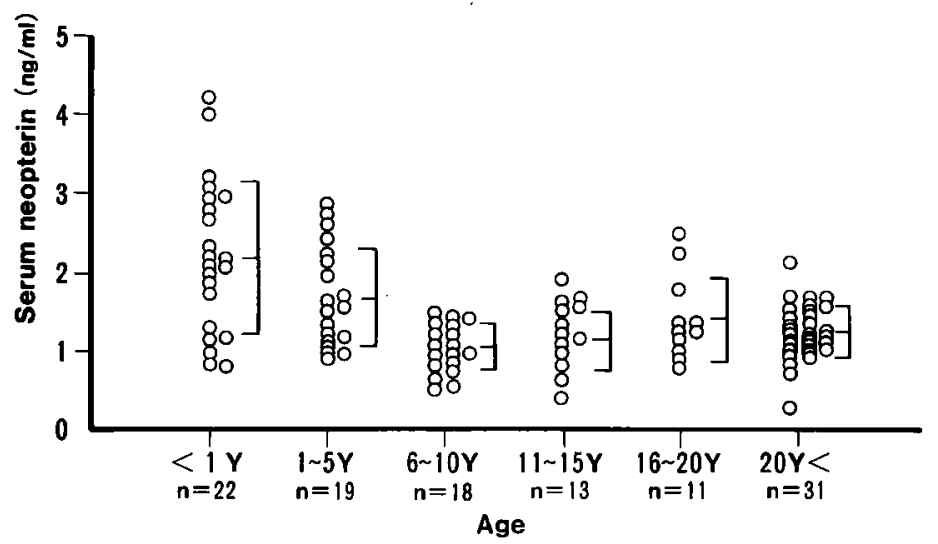

图 1 Serum neopterin levels in normal controls

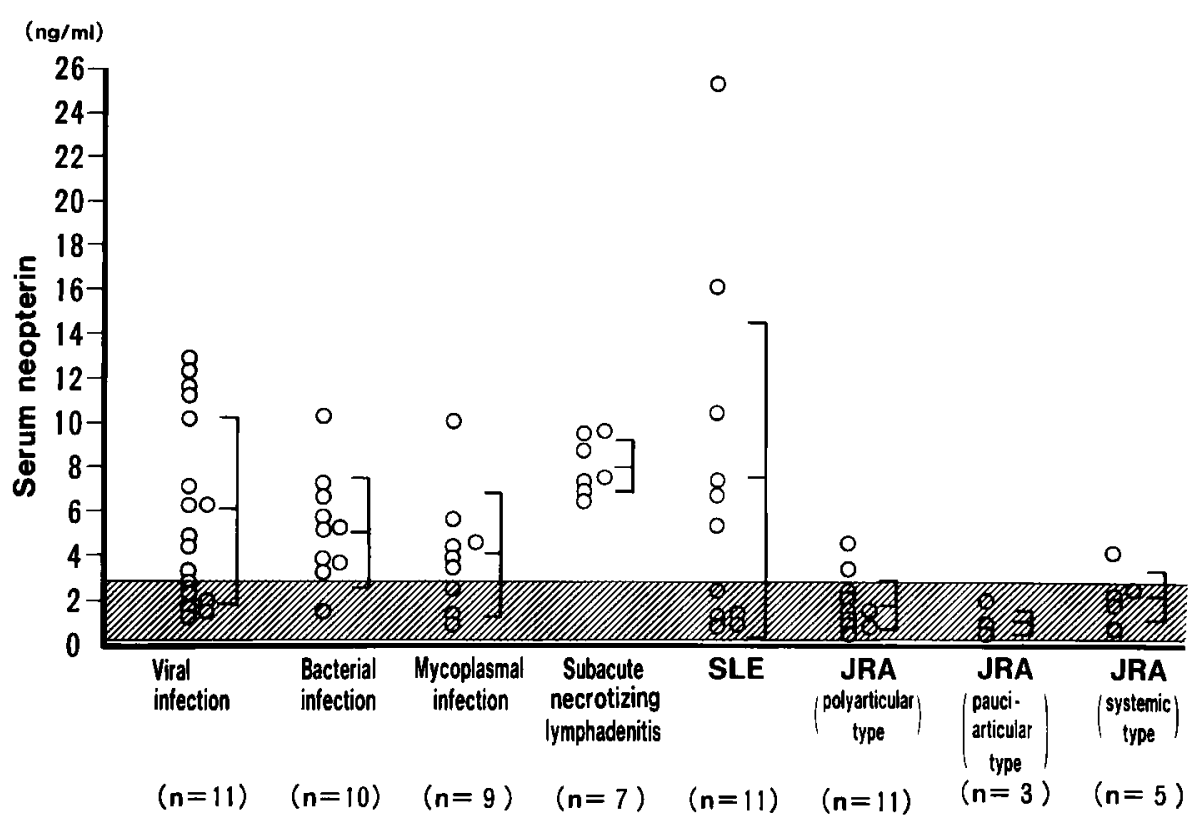

WIIT normal range

图 2 Serum neopterin levels in pediatrics inflammatory diseases 


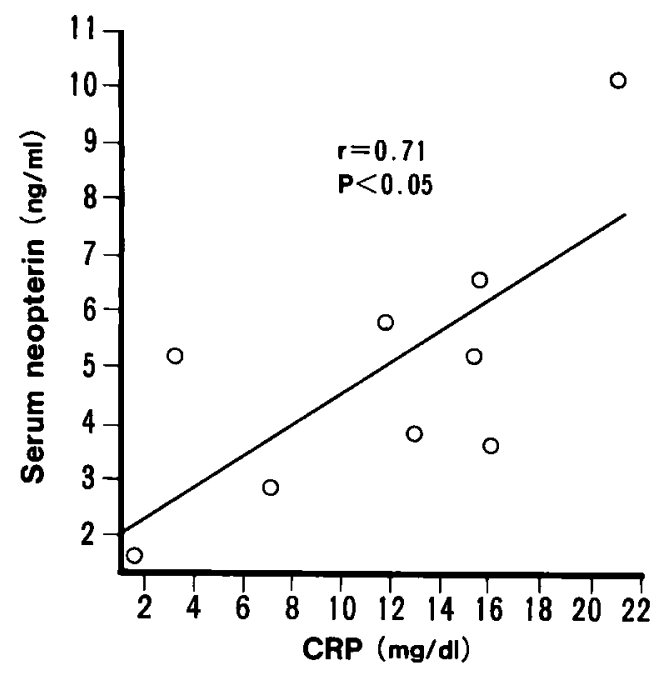

図 3-a Serum neopterin levels in patients with bacterial infection, as compared with CRP

重症細菌性感染症の急性期（入院時）では5.04士 $2.50 \mathrm{ng} / \mathrm{ml}$ で正常值に比べ，有意に高い傾向を認め た $(\mathrm{p}<0.01)$. 要急性壊死性リンパ節炎では, $6.93 \pm 2.18 \mathrm{ng} / \mathrm{m} l$ で正常值より有意に高值を示した

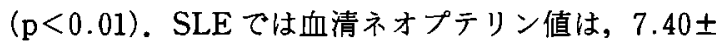
$7.15 \mathrm{ng} / \mathrm{ml}$ で高值を示した。 JRA では全身型, 多関 節型, 少関節型とも病型で変化はなく, 正常值と比べ 差が認められなかった。

3. 細菌感染症, ウイルス疾患における血清ネオプ テリンと他の炎症反応との比較（図 3-a，b)

細菌感染症における急性期の血清ネオプテリンと血 清 CRP の相関を求めると, 相関係数 $\mathrm{r}=0.71 \quad(\mathrm{n}=9)$ と有意の相関を示した $(\mathrm{p}<0.05$ ) (図 3-a). ウイル 不感症急性期においては細菌感染症とは異なり，血 清 CRP と血清ネオプテリンとはまったく相関が認め られなかった（図 3-b)。また，細菌感染症およびウ イルス感染症における赤沈值と血清ネオプテリンも CRP と同様に相関は認めなかった。

\section{SLE の病期における血清ネオプテリン值の変} 化（図 4)

SLE active stage, inactive stage に分け, 血清 ネオプテリン值を検討した. active stageでは, $10.85 \pm 6.89 \mathrm{ng} / \mathrm{m} l$ で有意に血清ネオプテリン值は正 常值に比べ上昇していた $(\mathrm{p}<0.01)$. inactive stage

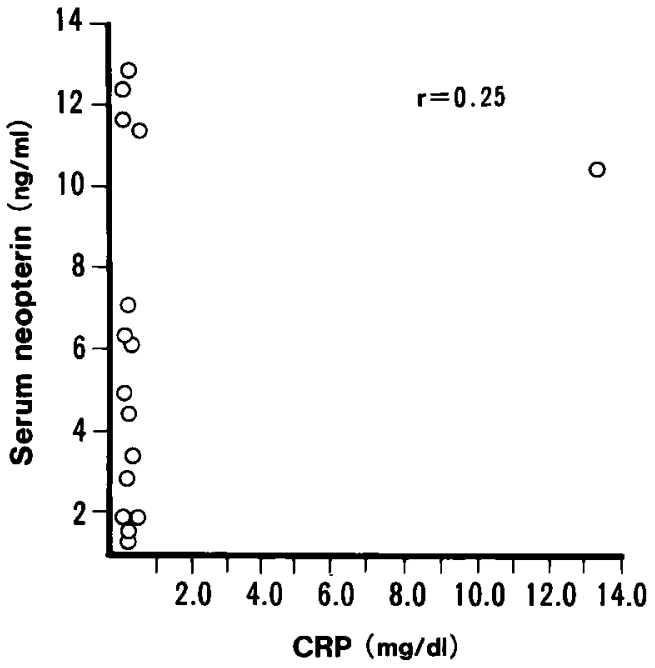

図 3-b Serum neopterin levels in patients with viral infection, as compared with CRP

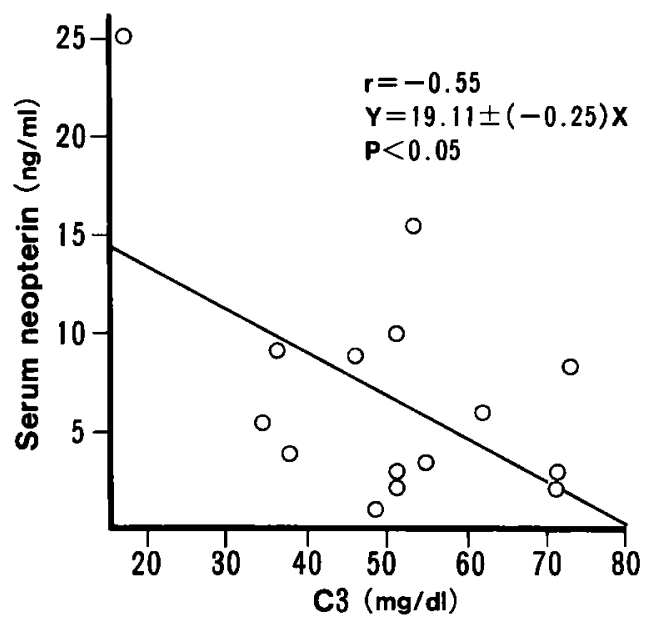

图 4 Serum neopterin levels in patients with SLE

では $1.38 \pm 0.59 \mathrm{ng} / \mathrm{m} l$ と正常值と比べ有意差がなか つた。またJRAにおいては active stage, inactive stage ともそれぞれ $2.40 \pm 1.42 \mathrm{ng} / \mathrm{m} l, 1.93 \pm 1.19$ $\mathrm{ng} / \mathrm{m} l$ で有意差は認めなかった。

\section{SLE における血清ネオプテリンと他の疾患活 動性の指標との比較（図 5 )}

以下の SLEの症例に関しては active stage の SLE に限り検討した。血清 CRP と血清ネオプテリンとの 相関について検討したところ，両者には相関関係は認 


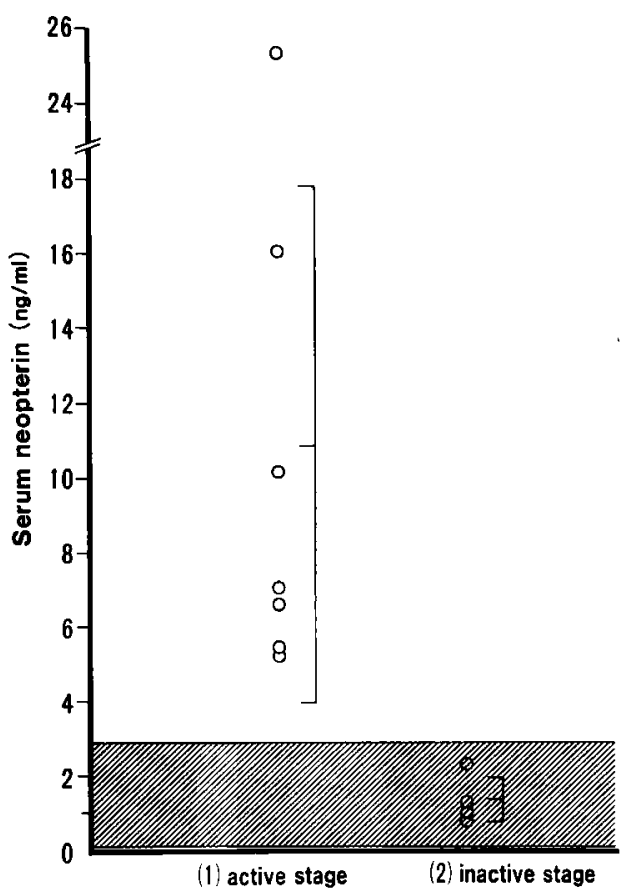

图 5 Serum neopterin levels in patients with active stage of SLE, as compared with C3
めなかった。また赤沈值と血清ネオプテリンとの間に も相関は認めなかった。次にSLEの疾患活動性と関 係があるといわれている補体と血清ネオプテリンとの 関係につき検討した．C3と血清ネオプテリンは有意 な負の相関関係がみられた（図 5 ）が, C 4, CH 50 とはそれぞれ低值であった症例は血清ネオプテリンが 上昇しているという傾向は認めたが, 有意な相関は得 られなかった。

\section{6. 臨床経過と血清ネオプテリンの関係（図 6)}

Case 1 (図 6-a) は, SLEの 13 歳の症例である. 回盲部血栓性静脈炎で発症, 1 年後発熱とともに四肢 の知覚異常と低下, 四肢の弛緩性麻瘦, DIC, 全身浮 腫, 精神不稳状態などのさまざまな臨床症状を呈し, 他覚的にも左視床梗塞, 左側頭葉出血を頭部 CT 所見 で認め，CNSループス抒よび多発神経炎と診断した。 急性期に血清ネオプテリンは $25.3 \mathrm{ng} / \mathrm{m} l$ と上昇して おり，回復期には $5.3 \mathrm{ng} / \mathrm{m} l$ と低下し，血清ネオプ テリンの変動は病勢と一致して変動した.

Case 2（図 6-b）は，JRAに合併したSLEの 12 歳の女児である。発熱, 全身性間代性痙摹, 意識障害
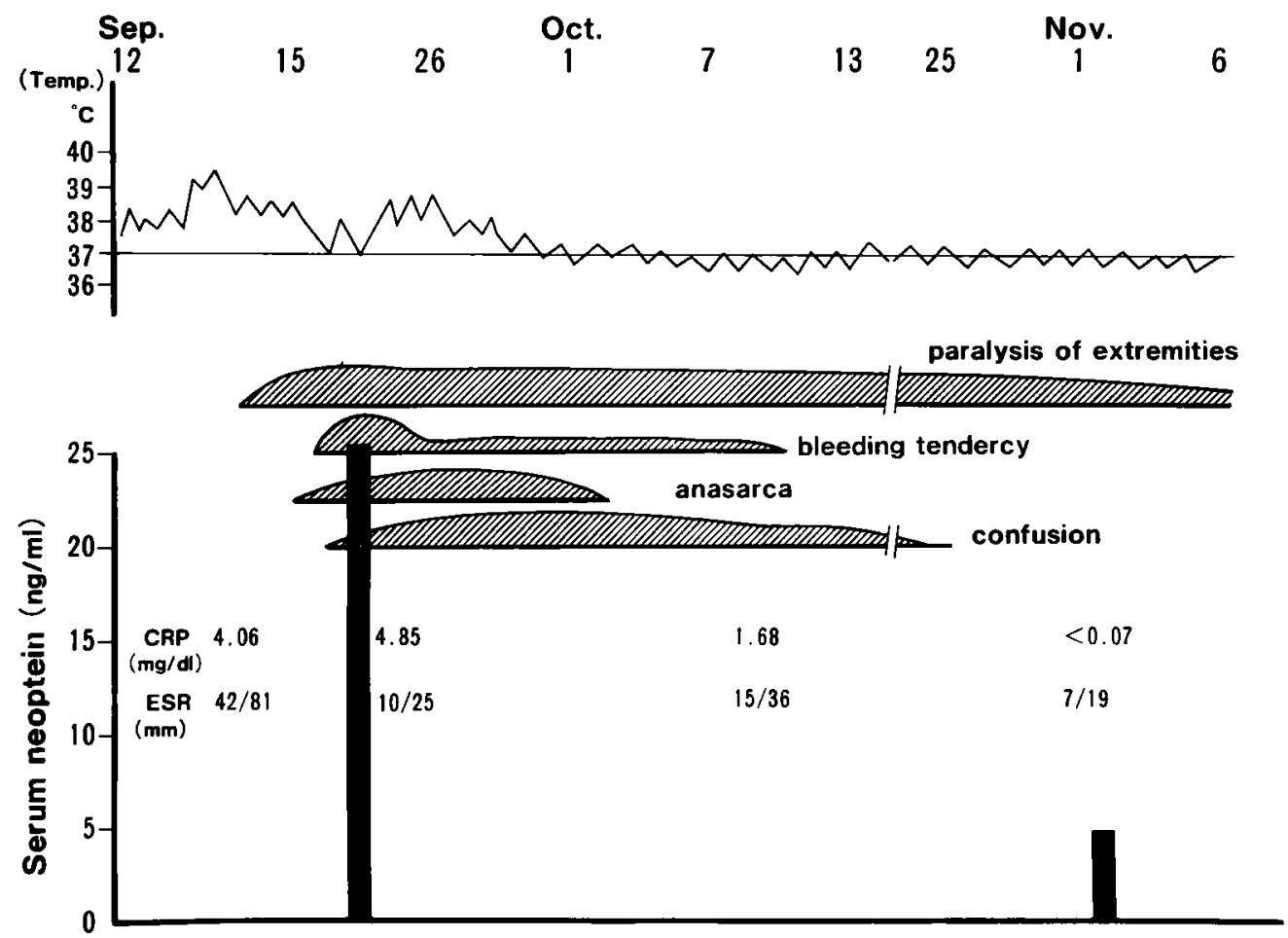

龱 6-a Clinical course and serum neopterin levels in case 1 13 years old (CNS lupus) 


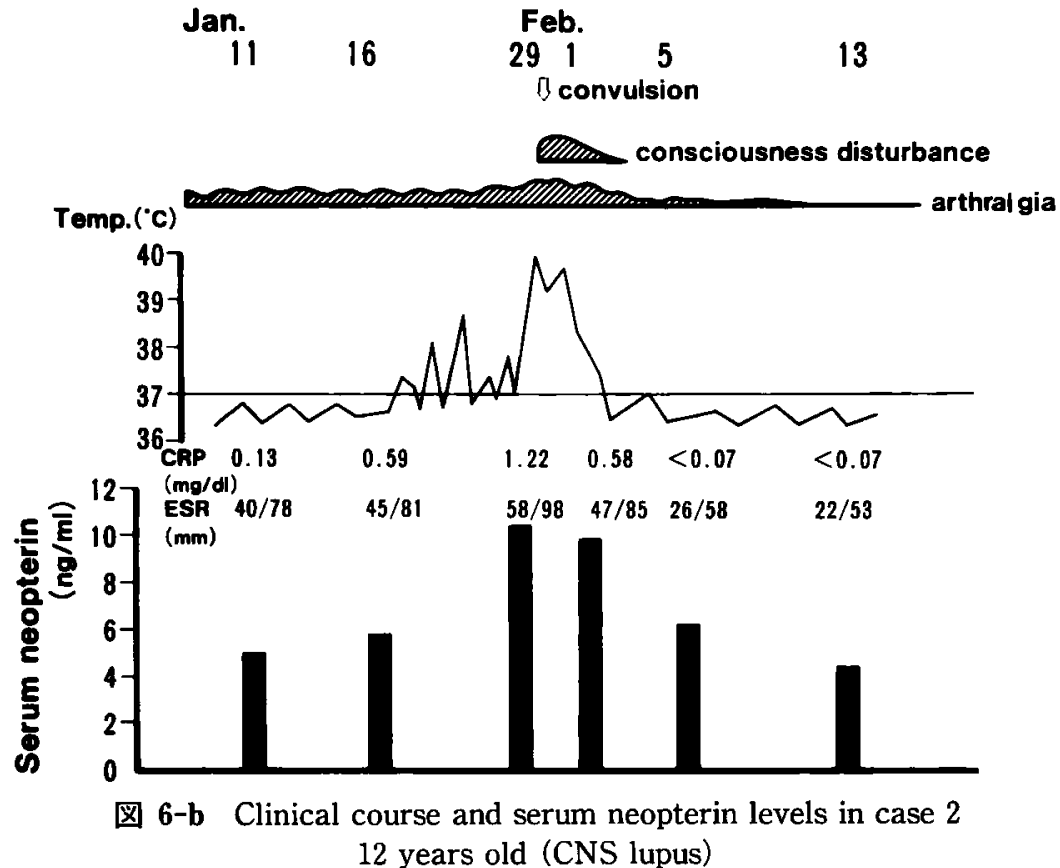

Jan. Feb.

$28 \quad 1$

$\begin{array}{lllll}7 & 13 & 20 & 23 & 26 \\ & & & \end{array}$

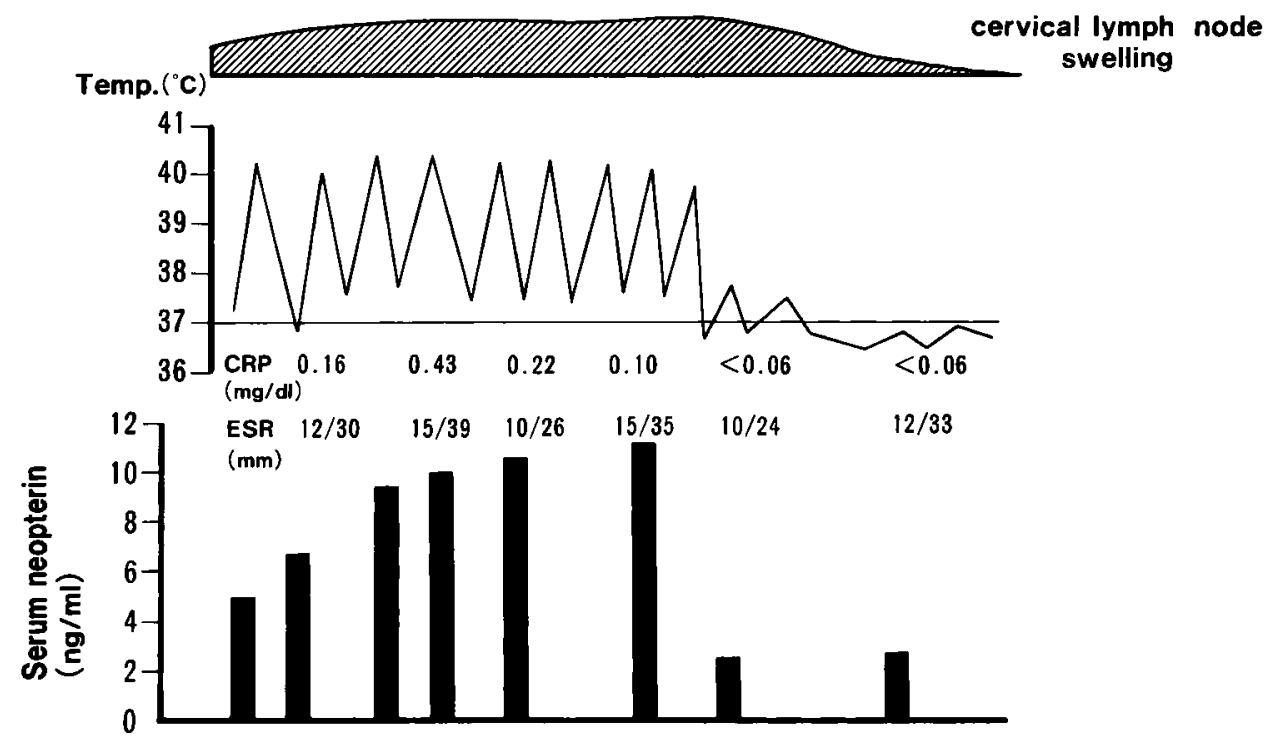

图 6-c Clinical course and serum neopterin levels in case 3 13 years old (Subacute necrotizing lymphadenitis) 
がみられ，髄液中の蛋白，ガンマグロブリン值は増加 を示し，回復期に一致して低下した。

Case 3（図 6-c）は，亜急性壊死性リンパ節炎の13 歳の症例である，診断は頝部リンパ節生検により行っ た.ガンマグロブリン製剤により検查所見ならびに臨 床症状の改善がみられた。この症例でも臨床症状にま ったく一致して血清ネオプテリンが変動した.

\section{IV. 考 察}

ネオプテリンは GTPから産生される分子量 253 の 低分子物質である。 その代謝産物である L-5，6，7， 8 tetrahydrobiopterin（BH 4) は神経伝達物質であ るカテコラミンやセロトニンあるいはチロシン合成の 補酵素となる、リンパ球，肝細胞などの細胞では，D $-7,8$, - dihydroneopterin triphoshate (NH 2 P 3) から䤃素反応 (dihydroneopterin-triphosphate converting enzyme) により BH 4 へ合成されてい く、ところが単球は dihydroneopterin-triphosphate converting enzymeをもたないため, NH 2 P 3 から ネオプテリンを産生するのに対し，単球以外の細胞 (リンパ球など）ではNH 2 P 3 はすべて BH 4 とな り，ネオプテリンを産生しない.そのためネオプテリ ンを産生するのは単球のみであるといわれている21.

In vitroにおいては単球のネオプテリン産生能は IFN- $\gamma$ により増強され, その産生能は単球のスーパ 一オキサイド産生能と相関するといわれている22).ま た，われわれは in vitroにおいて血管内皮細胞も単球 と同様に IFN- $\gamma$ 刺激によりネオプテリンを産生する ことを報告した ${ }^{23)}$. 体液中のネオプテリンの増加は， 種々の刺激に起因する単球の活性化によるといわれて いる ${ }^{24)}$ が，同時に血管内皮細胞の活性化も反映してい る可能性がある。血清でのネオプテリンの上昇してい る場合, IFN- $\gamma$ の上昇による単球の活性化と IFN- $\gamma$ 以外の単球活性化因子による単球の活性化によるもの と思われる。

ネオプテリンをin vivo で測定した報告では，特に 葴器移植時の拒絶反応の早期発見, AIDS の重症度な どの判定に有用といわれ，その他の疾患にも臨床応用 が期待されている。しかし，小児における年䶗別の正 常值がまだ報告されていない.そこでわれわれは小児 における血清ネオプテリンの正常值について検討し た. 乳幼児期においては，それ以後の年齢の時期に比 べ高值を示した，その理由は明らかでないが，乳幼坚 期においてはさまざまな感染に頻繁に暴露される機会
が多いため，単球がすでに activateされている状態 にあるのではないかとも考えられる。しかし，新生児 期には IFN- $\boldsymbol{y}$ の産生低下があるとの報告もあり ${ }^{25)}$, この場合の血清ネオプテリン高値の原因はIFN- $\gamma$ で はなく, 別の機序による単球活性化機構によるものと 考えられる。

小児期における各疾患では, 細菌性疾患, ウイルス 性疾患などの感染症ではともに高值がみられたが，疾 患の重症度とは相関がみられなかった.しかし, SLE では active stageに高值をとり, inactive stageでは 正常值と差がみられなかったことより病期の判定に有 用と思われた. SLEにおける中枢神経, 末梢神経の 合併症, 急性腹症などの発症機序には血管炎の関与が 考えられる．血管炎の発症機序に重要な役割を担うと 考えられる血管内皮細胞, 単球の活性化がこの疾患で のネオプテリン産生六進の機序を説明できると思われ る.一方，JRAにおいては全身型, 多関節型, 少関 節型の各病型, 病期いずれも健常群と差を認めなかっ た.また, SLEでは active stageにおいて血中 IFN $\gamma$ は高値を示し, RAでは血中 IFN- $\gamma$ は一定の傾向 は認められなかったと報告されており ${ }^{26)}$, SLEと JRAの血清ネオプテリン值の相違は, IFN-rの上昇 の程度によるものかもしれない.

亜急性壊死性りンパ節炎は，わが国に比較的多くみ られる原因不明の疾患であるが, 病理学的にはリンパ 組織内のリンパ球はほとんど壊死に陥りマクロファー ジのみ残存しているという特徴がある。また，一部の 亜急性壊死性りンパ節炎では骨䯣で赤血球貪食を示し たという報告がある27)．西急性壊死性リンパ節炎にお いて血清ネオプテリンが他の感染症と比べ高值をとつ たが，この疾患がなんらかの原因で単球，マクロフ.ア ージが活性化されている可能性が十分あり，そのため 血清ネオプテリンが上昇したと考えられた。この疾患 でどのような機序で単球が活性化されているのかを検 討するのは発症機序解明の一助となることが期待され る.

ネオプテリンは腎臓で排泄されるため, 腎機能障害 では血清ネオプテリンが上昇するが, 今回検討に使用 した症例は血清クレアチニン值はすべて正常であり， 腎機能は正常であったと思われる症例を用いた。今後 血清ネオプテリンを検討するのにあたり，腎機能を検 討しておく必要がある。

血清ネオプテリンは炎症性疾患の急性期に上昇し, 病勢を反映することから一つの急性期反応物質である 
と考えられる.しかし，ネオプテリンは単球で産生さ れるのに対し，CRPなど多くの急性期反応物質は肝 細胞で産生される．また CRP および赤沈值は細菌感 染症ではよく病势を反映するがウイルス感染, 膠原 病, 垔急性壊死性リンパ節炎などの疾患では病勢と一 致しないことが多い.これに対し，血清ネオプテリン は, SLE, 亜急性壊死性リンパ節炎で病勢と平行して 上昇し，他の急性期反応物質では知ることのできない 炎症を反映するなどの点でいままで知られている急性 期反応物質とは異なる，このように血清ネオプテリン は CRP など従来より知られている急性期反応物質と は異質なマーカーと考えられ, 今後の臨床応用が期待 できると思われた。

\section{V. 結 語}

1）抗ネオプテリン抗体を用いた RIA 法により正 常小児ならびに各種炎症性疾患の血清ネオプテリンを 測定した.

2）年齢群別の正常值の比較では，乳児期おょび幼 児期で学童期, 青年期, 成人期の各群に比し高値をと った.

3）血清ネオプテリン值は細菌性疾患，ウイルス性

\section{文}

1) Kaufmann, S. : The structure of phenylalanine hydroxylation cofactor. Proc. Natl. Acad. Sci. USA, 50 : 1085 1093, 1963.

2) Schoeden, G., Niederwiser, A., Troppmair, J., Huber, Ch. : Biochemical and clinical aspects of pteridines, Vol. 4, Edicated by Wachter, H., Curtis, H-Ch., Pfleiderer, W., Walter de Gruyter, Berlin, 1985, pp. 369 377.

3) Huber, Ch., Batchelor, J.R., Fuchs, D., Hausen, A., Lang, A., Niederwiser, D., Reibnegger, G., Swetly, P., Troppmair, J., Wachter, H. : Immune response-associated production of neopterin. Release from macrophages primarily under control of interferongamma. J. Exp. Med., 160 : 310 316, 1984.

4) Fuchs, D., Hausen, A., Reibnegger, G., Werner, E.R., Dierich, M.P., Wachter, H. : Neopterin as a marker for activated cellmediated immunity. Immunology Today, 9 :
疾患では正常值より高値を示したが, 疾患の重症度と は相関がみられなかった. JRAでは各病型, 病期と も正常值と差がみられなかった。それに対し，SLE, 要急性壊死性リンパ節炎では血清ネオプテリン值は高 値を示した.

4）血清ネオプテリン值は SLEの active stage で は高值をとり, inactive stage では正常值と差がみら れず，疾患活動性の判定に有用と思われた，悪急性壊 死性リンパ節炎においても臨床症状と一致して変化を 示し,これらの疾患活動性を評価するのにはよい指標 であると思われた。

稿を終えるにあたり御指導, 御校閱を頂いた東京慈 恵会医科大学小児科学教室教授 前川喜平先生ならび に研究の御指導を頂いた埼玉県立小児医療センター感 染免疫アレルギー科 大石 勉先生, 研究の協力を頂 いた同・放射線部 山本英明氏，坂本政文氏に深謝いた します。

本稿の要旨は第 18 回日本臨床免疫学会総会（1990 年6月）にて報告した.

なお本研究の一部は, 厚生省特定疾患兔疫不全症候 群調查研究班の研究費によって行われた.

$150 \sim 155,1988$.

5) Margreiter, R., Fuchs, D., Hausen, A., Huber, C., Reibnegger, G., Spielberger, M., Wachter, H. : Neopterin as a new biochemical marker for diagnosis of allograft rejection. Experience based upon evaluation of 100 consecutive cases. Transplantaion, $36: 650 \sim 653$, 1983.

6) Schäfer, A.J., Daniel, V., Drekorn, K., Opelz, C. : Assessment of plasma neopterin in clinical kidney transplantaion. Transplantaion, $41:$ 454 459, 1986.

7) Niederwieser, D., Huber, C., Gratwohl, A., Bannert, P., Fuchs, D., Huasen, A., Reibnegger, G., Speck, B., Wachter, H. : Neopterin as a new biochemical marker in the clinical monitoring of bone marrow transplant recipients. Transplantation, $38: 497 \sim 500,1984$.

8) Woloszczuk, W., Schwarz, M., Havel, M., 
Laczkovics, A., Muller, M.M. : Neopterin and interferon gamma serum levels in patients with heart and kidney transplants. J. Clin. Chem. Clin. Biochem., $24: 729 \sim 734$, 1986.

9) Reibnegger, G., Fuchs, D., Grubauer, G., Hausen, A., Wachter, H. : Biochemical and clinical aspects of pteridines. Edited by Pfleiderer, W., Wachter, H., Crutius, H.C., Walter de Gruyter, Berlin, 1984, pp. 443 447.

10) Bäckman, L., Ringden, O., Bjärkhem, I.: Monitoring of serum neopterin levels in renal transplant recipients. Increased values during impaired renal function and $\mathrm{CMV}$ infection. Nephron., 46:319 322, 1987.

11) Sunder-Pla $\beta$ mann, G., Stockenhuber, F., Balcke, P. : Serum IL-2 activity in kidney graft recipients. Kidney Int., 33:453, 1988.

12) Smillie, A.E., Rigby, R.J., Petrie, J.J.B. : Monitoring the response to anti-rejection therapy with serum neopterin. Transplant. Proc., $21: 1869 \sim 1870,1989$.

13) Strohmaier, W., Redel, H., Schlag, G., Inthor$\mathrm{n}, \mathrm{D}$. : D-erythro-neopterin plasma levels in intensive care patients with and without septic complications. Critical. Care. Medicine, $15: 757 \sim 760,1987$.

14）飯塚忠史・出沢 亨・篠原邦一・上村 茂・小 池通夫：川崎病に扔ける冠動脈障害と尿中ネオ プテリン. 日児誌, 91：705〜 709, 1987.

15) Alzer, G.M., Diemer, O., Strumper, R., Rohe, M. : Neopterin production in inflamed knee joints. : high levels in synovial fluids. Rheumatol. Int., $6: 151 \sim 154,1986$.

16) Wachter, H., Huase, A., Grassmayr, K. : Erhohte Ausscheidung von Neopterin im Harn von Patienten mit malignen Tumoren und mit Viruserkrankungen. Hoppe-Seyler's Z. Physiol. Chem., 360 : 1957 1960, 1979.

17) Reibnegger, G.J., Bichler, A.H., Dapunt, O., Fuchs, D., Fuith, L.C., Hausen, A., Hetzel, H. M., Lutz, H., Werner, E.R., Wachter, H. : Neopterin as a prognostic indicator in patients with carninoma of the uterine cervix.
Cancer Res., 46: 950 955, 1986.

18) Lefrere, J.J., Courouce, A.M., Lambin, P., Fine, J.M., Doinel, C., Salmon, C. : Clinical and biological features in the 12 month preceding onset of AIDS in HIV-infected subjects. J. AIDS, $2: 100 \sim 101,1989$.

19) Goebel, F.D., Erfle, V., Piechowiak, H., Hien, P., Scholz, H., Helmann, R. : The relations of HTLV-III antibodies to neopterin and $\beta_{2}$ microglobulin in the serum of patients with AIDS or persons at risk. Edited by Wachter, H., Crutis, H.C., Pfleiderer, W., Walter de Gruyter, Berlin, 1985, pp. 319.

20) Melmed, R.N., Taylor, J.M.G., Detels, R., Bozorrgmehri, M., Fahey, J.L. : Serum neopterin changes in HIV-infected subjects. Indicator of significant pathology, $\mathrm{CD} 4 \mathrm{~T}$ cell changes and the development of AIDS. J. AIDS, $2: 70 \sim 76,1989$.

21) Zeigler, I. : Accumulation and release of pteridines during stimulation of human peripheral blood mononuclear cells. Participation in the control of antigen induced $\mathrm{T}$-cell expansion. Edited by Wachter, H., Crutius, H. Ch., Pfleiderer, W., Walter de Gruyter, 1985, pp. $347 \sim 361$.

22) Nathan, C.F. : Peroxide and pteridine. A hypothesis on the regulation of macrophage anti-microbial activity by interferon-gamma. Interferon, $7: 123 \sim 143,1986$.

23）関 孝 - 大石 勉 - 久保政勝 - 坂本政文 - 黒川 晴幸・新井 孝・山本英明・城 宏輔・森 彪: 七ト血管内皮細胞からのネオプテリン分泌. 医 学のあゆみ, $152: 251 〜 252,1990$.

24) Huber, C., Fuchs, D., Hausen, A., Margreiter, R., Reibnegger, G., Spielberger, M., Wachter, $\mathrm{H}$. : Pteridines as a new marker to detect human $\mathrm{T}$-cell activated by allogenic or modified self major histocompatibility complex (MHC) determinants. J. Immunol., $130: 1047 \sim 1050,1983$.

25) Wakasugi, N., Virelizer, J., Arenzana-Seisdedos, F., Rothhut, B., Huerta, J.M., RussoMarie, F., Fiers, W. : Defective IFN $-\gamma$ pro- 
duction in the human neonate. J. Immunol., $134: 712 \sim 716,1985$.

26）船内正慧 - 山添 康 - 東谷澄彦 - 東川光弘 -千 田史郎・喜田正豪・堀内 篤：翏原病に打㚈る 血中インターロイキン 4 と $\gamma$-インターフェロ
ンの検討. アレルギー, $39: 1320,1990$.

27）稲葉俊哉・柳沼章弘・花田良二・林 泰秀・山 本圭子：骨髄に histiocyte の増殖を認め, 沉血 球減少を伴った亜急性壊死性リンパ節炎の1 例. 臨血, 29:1120 1124, 1988. 